\title{
Risk assessment of arsenic-induced internal cancer at long-term low dose exposure
}

\author{
Chung-Min Liao ${ }^{\mathrm{a}, *}$, Huan-Hsiang Shen ${ }^{\mathrm{a}}$, Chi-Ling Chen ${ }^{\mathrm{b}}$, Ling-I Hsu ${ }^{\mathrm{c}}$, Tzu-Ling Lin ${ }^{\mathrm{a}}$, \\ Szu-Chieh Chen ${ }^{\mathrm{d}}$, Chien-Jen Chen ${ }^{\mathrm{b}, \mathrm{e}}$ \\ a Department of Bioenvironmental Systems Engineering, National Taiwan University, Taipei 10617, Taiwan ROC \\ b Genomics Research Center, Academic Sinica, Taipei 11529, Taiwan ROC \\ ${ }^{\mathrm{c}}$ Graduate Institute of Clinical Medicine, College of Medicine, National Taiwan University, Taipei, Taiwan ROC \\ ${ }^{\mathrm{d}}$ Department of Public Health, College of Health Care and Management, Chung Shan Medical University, \\ Taichung 40201, Taiwan ROC \\ e Graduate Institute of Epidemiology, College of Public Health, National Taiwan University, Taipei 11018, Taiwan ROC
}

\section{A R T I C L E I N F O}

\section{Article history:}

Received 1 July 2008

Received in revised form 8 October 2008

Accepted 9 October 2008

Available online 5 November 2008

\section{Keywords:}

Arsenic

Dose-response model

Risk assessment

Cancer

Drinking water

\begin{abstract}
A B S T R A C T
Previous epidemiological studies have indicated that ingested inorganic arsenic is strongly associated with a wide spectrum of internal cancers. Little is conducted, however, to assess health effects at longterm low dose exposures by linking biologically based mechanistic models and arsenic epidemiological data. We present an integrated approach by linking the Weibull dose-response function and a physiologically based pharmacokinetic (PBPK) model to estimate reference arsenic guideline. The proposed epidemiological data are based on an 8 years follow-up study of 10,138 residents in arseniasis-endemic areas in southwestern and northeastern Taiwan. The $0.01 \%$ and $1 \%$ excess lifetime cancer risk based pointof-departure analysis were adopted to quantify the internal cancer risks from arsenic in drinking water. Positive relationships between arsenic exposures and cumulative incidence ratios of bladder, lung, and urinary-related cancers were found using Weibull dose-response model $r^{2}=0.58-0.89$ ). The result shows that the reference arsenic guideline is recommended to be $3.4 \mu \mathrm{g} \mathrm{L}^{-1}$ based on male bladder cancer with an excess risk of $10^{-4}$ for a 75 -year lifetime exposure. The likelihood of reference arsenic guideline and excess lifetime cancer risk estimates range from $1.9-10.2 \mu \mathrm{g} \mathrm{L}^{-1}$ and $2.84 \times 10^{-5}$ to $1.96 \times 10^{-4}$, respectively, based on the drinking water uptake rates of $1.08-6.52 \mathrm{Ld}^{-1}$. This study implicates that the Weibull model-based arsenic epidemiological and the PBPK framework can provide a scientific basis to quantify internal cancer risks from arsenic in drinking water and to further recommend the reference drinking water arsenic guideline.
\end{abstract}

(c) 2008 Elsevier B.V. All rights reserved.

\section{Introduction}

Previous epidemiological studies have indicated that ingested inorganic arsenic is strongly associated with a wide spectrum of adverse health outcomes, primary cancers (lung, bladder, kidney, skin) and other chronic diseases such as dermal, cardiovascular, neurological, and diabetic effects in arseniasis-endemic area in southwestern and northeastern Taiwan [1-8]. Chronic and systemic exposure to arsenic is known to lead to serious disorders, such as vascular diseases (blackfoot disease (BFD) and hypertension) and irritations of the skin and mucous membranes as well as dermatitis, keratosis, and melanosis. The clinical manifestations of chronic

\footnotetext{
* Corresponding author. Tel.: +8862 2363 4512; fax: +88622362 6433 .

E-mail addresses: cmliao@ccms.ntu.edu.tw, cmliao@ntu.edu.tw (C.-M. Liao).
}

arsenic intoxication are referred to as arsenicosis (hyperpigmentation and keratosis).

Chronic toxicity is observed from exposure to drinking water that contains ppb levels of inorganic arsenic [9]. The final regulation by the U.S. Environmental Protection Agency (USEPA) on arsenic in drinking water lowered the standard from 50 to $10 \mu \mathrm{g} \mathrm{L}^{-1}$ [10]. There are still great uncertainties on health effects of arsenic at low doses. Research is needed to investigate and assess human health effects of arsenic at long-term low dose exposures using biologically based mechanistic models. Humans are potentially exposed to multiple valence forms or metabolites of arsenic. As(V) and $\mathrm{As}(\mathrm{III})$ exhibit very different toxicities and biokinetics, as do the methylated metabolites, monomethyl arsonate (MMA) and dimethyl arsonate (DMA), leading to species-specific differences in detoxification, metabolism, or uptake or accumulation in target tissues [11]. The residents are exposed to inorganic arsenic primar- 
ily through natural enrichment of drinking well water via the oral route. Inorganic arsenic is methylated into less toxic organic forms in the body via alternating reduction of $\mathrm{As}(\mathrm{V})$ to $\mathrm{As}(\mathrm{III})$ and oxidative methylation to MMA and DMA, which are excreted mainly in the urine.

The most recent physiologically based pharmacokinetic (PBPK) models for arsenic have a number of similarities [12]. Yu [13] extended his own developed parsimonious PBPK model [14] to fit the human child including all arsenic species, and considering both reductive metabolism and methylation. Yu [15] further refined the model to fit the human adult, indicating that the input parameters that most significantly affected the output of the model were the maximum methylation reaction rate, the level of GSH for determination of the reaction rate of $\mathrm{As}(\mathrm{V})$ to $\mathrm{As}(\mathrm{III})$, and the urinary excretion constants. Mann et al. [16,17] have developed a PBPK model for arsenic in hamsters and rabbits, which was subsequently scaled to humans.

The choice of an appropriate dose-response model to represent pharmacodynamic (PD) characteristics is an important consideration in risk assessment. Generally, at high doses, most of the models are quite similar. At low doses, however, the log-logit and Weibull models are linear on a log-log scale, whereas the log-probit model has a substantial curvature and gives a much lower risk estimates. Christensen and Nyholm [18], ten Berge [19], and Kodell et al. [20] suggested that the Weibull model was particularly well suited for a long-term low dose exposure purpose on dose-response modeling on lifetime cancer risk estimation.

This paper is the first to report dose-response function for internal cancers based on an 8-year follow-up study of 10,138 residents in arseniasis-endemic areas in southwestern and northeastern Taiwan. The main aim of this study was to quantify internal cancer risks from arsenic in drinking water and to further estimate the reference arsenic guideline based on the proposed PBPK and Weibull modelbased epidemiological framework in arseniasis-endemic areas. This study can provide a scientific basis for risk analysis to enhance broad risk management strategies for the regulatory authority.

\section{Materials and methods}

\subsection{Quantitative arsenic epidemiological data}

Fig. 1 shows the research framework for interaction among epidemiological data, Weibull model, and internal cancer risks from arsenic in drinking water. The incorporation of external exposure concentration (EEC) to internal exposure concentration (IEC) was considered in the age-stage PBPK model to account for the variability of risk estimates.

Thanks to Blackfoot Disease Study Group (BDSG) in Taiwan who has provided the remarkable dataset related to arsenic epidemiology in arseniasis-endemic areas in Taiwan. The arsenic epidemiological data give us the opportunity to test all theoretical considerations of arsenic exposure effects and quantify its strength. We appraised the dataset from the cohort study in arseniasisendemic areas in Taiwan to quantitatively reconstruct arsenic epidemiology data (Tables 1 and 2). BDSG used a standardized questionnaire interview to collect information including arsenic exposure, cigarette smoking and alcohol consumption, and other risk factors such as sociodemographic characteristics, residential and occupational history, and history of drinking well water by two well-trained public health nurses. A total of 2050 residents in four townships of Peimen, Hsuehchia, Putai, and Ichu on the southwestern coast and 8088 in four townships of Tungshan, Chuangwei, Chiaohsi, and Wuchieh in the northeastern Lanyang Plain were followed up for an average period of 8 years. A detailed description of the recruitment procedure for cohort studies and cancer cases ascertainment has been reported previously [7,20].

Residents in the southwestern endemic area had consumed artesian well water (100-300 $\mathrm{m}$ in depth) for more than 50 years

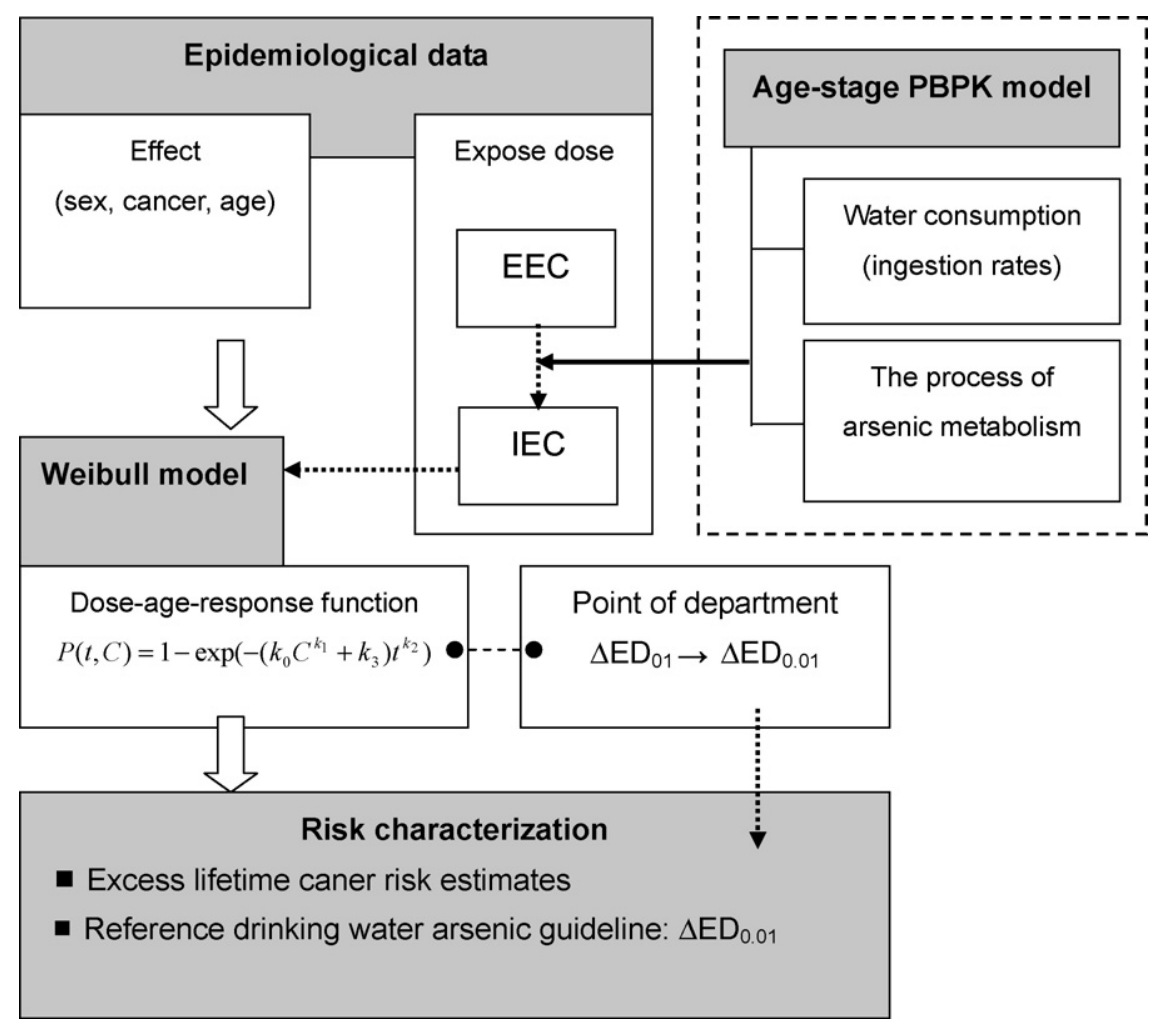

Fig. 1. A conceptual diagram showing Weibull model associated with epidemiological data and PBPK model to estimate cancer risk. 
Table 1

Distribution of cancer cases and the surveyed male populations by age group and concentration of arsenic in the arseniasis-endemic areas in Taiwan.

\begin{tabular}{|c|c|c|c|c|c|c|c|}
\hline \multirow[t]{2}{*}{ As concentration $\left(\mu \mathrm{g} \mathrm{L}^{-1}\right)$} & \multicolumn{7}{|l|}{ Age group (year) } \\
\hline & Cancer & $<40$ & $40-49$ & $50-59$ & $60-69$ & $>70$ & Total \\
\hline \multicolumn{8}{|l|}{ Male } \\
\hline \multirow[t]{4}{*}{$<10$} & Liver & $62(0)^{a}$ & 293(5) & $448(13)$ & $377(8)$ & $211(4)$ & 1391(30) \\
\hline & Lung $^{\mathrm{b}}$ & $26(0)$ & $96(0)$ & $107(0)$ & $70(1)$ & $46(1)$ & $345(2)$ \\
\hline & Bladder & $62(0)$ & 293(1) & $448(2)$ & $377(2)$ & $211(2)$ & 1391(7) \\
\hline & Bladder, kidney, urinary & $62(0,0,0)$ & $293(1,1,2)$ & $448(2,2,4)$ & $377(2,0,2)$ & $211(2,1,3)$ & - \\
\hline \multirow[t]{4}{*}{$10-49$} & Liver & $2(0)$ & $232(0)$ & $357(5)$ & $312(4)$ & $192(1)$ & $1095(10)$ \\
\hline & Lung & $1(0)$ & $80(0)$ & $76(1)$ & $55(0)$ & $33(0)$ & 245(1) \\
\hline & Bladder & $2(0)$ & $232(0)$ & $357(1)$ & $312(1)$ & $192(1)$ & 1095(3) \\
\hline & Bladder, kidney, urinary & $2(0,0,0)$ & $232(0,0,0)$ & $357(1,1,2)$ & $312(1,0,1)$ & $192(1,0,1)$ & - \\
\hline \multirow[t]{4}{*}{$50-99$} & Liver & $1(0)$ & $78(1)$ & $165(2)$ & $145(1)$ & $79(1)$ & $468(5)$ \\
\hline & Lung & $1(0)$ & $19(0)$ & $37(0)$ & 19(1) & $15(0)$ & 91(1) \\
\hline & Bladder & $1(0)$ & $78(0)$ & $165(0)$ & $145(0)$ & $79(1)$ & $468(1)$ \\
\hline & Bladder, kidney, urinary & $1(0,0,0)$ & $78(0,0,0)$ & $165(0,1,1)$ & $145(0,0,0)$ & $79(1,0,1)$ & - \\
\hline \multirow[t]{4}{*}{$100-149$} & Liver & $1(0)$ & $71(1)$ & $90(0)$ & $76(0)$ & $33(1)$ & $271(2)$ \\
\hline & Lung & $0(0)$ & $21(0)$ & $21(0)$ & $14(0)$ & $6(0)$ & $62(0)$ \\
\hline & Bladder & $1(0)$ & $71(0)$ & $90(1)$ & $76(0)$ & $33(0)$ & $271(1)$ \\
\hline & Bladder, kidney, urinary & $1(0,0,0)$ & $71(0,0,0)$ & $90(1,0,1)$ & $76(0,0,0)$ & $33(0,0,0)$ & - \\
\hline \multirow[t]{4}{*}{$150-299$} & Liver & $2(0)$ & $51(0)$ & $65(3)$ & $65(0)$ & $35(0)$ & $218(3)$ \\
\hline & Lung & $0(0)$ & $18(0)$ & $22(0)$ & $15(0)$ & $9(0)$ & $64(0)$ \\
\hline & Bladder & $2(0)$ & $51(0)$ & $65(1)$ & $65(0)$ & $35(0)$ & $218(1)$ \\
\hline & Bladder, kidney, urinary & $2(0,0,0)$ & $51(0,0,0)$ & $65(1,0,1)$ & $65(0,0,0)$ & $35(0,0,0)$ & - \\
\hline \multirow[t]{4}{*}{$300-599$} & Liver & $4(0)$ & $39(1)$ & $97(3)$ & $62(4)$ & $47(1)$ & $249(9)$ \\
\hline & Lung & $4(0)$ & $12(0)$ & $23(0)$ & $9(0)$ & $13(0)$ & 61(0) \\
\hline & Bladder & $4(0)$ & $39(1)$ & $97(1)$ & $62(1)$ & $47(1)$ & $249(4)$ \\
\hline & Bladder, kidney, urinary & $4(0,0,0)$ & $39(1,0,1)$ & $97(1,1,2)$ & $62(1,0,1)$ & $47(1,1,2)$ & - \\
\hline \multirow[t]{4}{*}{$>600$} & Liver & $103(2)$ & $186(3)$ & $242(4)$ & $108(3)$ & $45(2)$ & $684(14)$ \\
\hline & Lung & $45(0)$ & $82(0)$ & $95(2)$ & $37(1)$ & $18(0)$ & $277(3)$ \\
\hline & Bladder & $103(2)$ & $186(6)$ & $242(14)$ & $108(6)$ & $45(3)$ & $684(31)$ \\
\hline & Bladder, kidney, urinary & $103(2,1,2)$ & $186(6,1,7)$ & $242(14,7,19)$ & $108(6,2,8)$ & $45(3,1,3)$ & - \\
\hline
\end{tabular}

a Observed number (cancer number).

b Excluding cigarette smokers.

before the implementation of the tap water supply system in the early 1960 . The estimated amount of ingested arsenic mainly from drinking water was $\geq 1 \mathrm{mg} \mathrm{d}^{-1}$ in this area [21]. Residences in the northeastern endemic area had consumed water from shallow well ( $<40 \mathrm{~m}$ in depth) since the late 1940 s through the early 1990 s, when the tap water system was implemented. Arsenic levels in well water in the northeastern Lanyang Plain ranged from $<0.15$ to $>3000 \mu \mathrm{g} \mathrm{L}^{-1}[20]$. The larger number of study participants $(10,138$ residents from southwestern and northeastern Taiwan), longer period of follow-up with more incident cancer cases, and wider range of arsenic exposure levels leads us with a unique opportunity to further investigate the dose-response relationship between ingested arsenic exposure and cancer risks.

\subsection{Weibull dose-response function}

Here we used the Weibull cumulative distribution function to account for the age-specific cumulative incidence ratio for human long-term exposure to low doses of arsenic,

$g(t, \varepsilon(C))=\varepsilon(C) k_{2} t^{k_{2}-1} \exp \left(-\varepsilon(C) t^{k_{2}}\right)$,

with

$\varepsilon(C)=k_{0} C^{k_{1}}+k_{3}$,

where $g(t, \varepsilon(C))$ represents the cancer-specific cumulative incidence ratio for human exposed to arsenic concentration $C\left(\mu \mathrm{g} \mathrm{L}^{-1}\right)$ at age $t$ (year), $\varepsilon(C)$ is the $C$-dependent shape parameter, and $k_{0}, k_{1}, k_{2}$, and $k_{3}$ are the cancer-specific best-fitted parameters. The best-fitted parameters of $k_{1}$ and $k_{2}$ may regard as the connection degree of the cumulative incidence ratio with arsenic concentration and age, respectively. The cumulative incidence ratio for human exposed to arsenic concentration $C$ at age $t$ can then be obtained by integral of Eq. (1) as

$$
\begin{aligned}
P(t, C) & =\int_{0}^{t} g(t, \varepsilon(C)) d t=1-\exp \left(-\varepsilon(C) t^{k_{2}}\right) \\
& =1-\exp \left(-\left(k_{0} C^{k_{1}}+k_{3}\right) t^{k_{2}}\right) .
\end{aligned}
$$

We employed TableCurve 3D (Version 4, AISN Software Inc., Mapleton, OR, USA) to perform model fitting to arsenic epidemiological data.

\subsection{PBPK model}

We appropriately refined the basic compartmental structure that has been previously employed in many PBPK models for arsenic exposure in humans $[13,15,17]$ to describe the absorption, distribution, metabolism, and elimination of arsenic in target organs. The tissue compartments included in the model were (Fig. 2A): lung, liver, kidney, GI tract, skin, muscle, richly and slowly perfused tissues in that each tissue compartment is interconnected by blood flow. Physiological parameters such as blood flow rates; organ volumes and water elimination were linking with the variation of body weight in the difference age stage (Table A1). Hence, PBPK model can estimate the arsenic concentration in tissues based on age-specific physiology stage.

The biotransformation of arsenic in the body consists of an oxidation/reduction and two methylation reactions (Fig. 2B). The oxidation/reduction of inorganic arsenic takes place in the plasma, 
Table 2

Distribution of cancer cases and the surveyed female populations by age group and concentration of arsenic in the arseniasis-endemic areas in Taiwan.

\begin{tabular}{|c|c|c|c|c|c|c|c|}
\hline \multirow[t]{2}{*}{ As concentration $\left(\mu \mathrm{gL}^{-1}\right)$} & \multicolumn{7}{|l|}{ Age group (year) } \\
\hline & Cancer & $<40$ & $40-49$ & $50-59$ & $60-69$ & $>70$ & Total \\
\hline \multicolumn{8}{|l|}{ Female } \\
\hline \multirow[t]{4}{*}{$<10$} & Liver & $78(0)^{a}$ & $310(0)$ & $450(2)$ & $315(1)$ & $240(2)$ & 1393(5) \\
\hline & Lung ${ }^{\mathrm{b}}$ & $78(0)$ & $306(1)$ & $441(3)$ & $301(5)$ & $226(3)$ & $1352(12)$ \\
\hline & Bladder & $78(0)$ & $310(1)$ & $450(3)$ & $315(1)$ & $240(0)$ & $1109(5)$ \\
\hline & Bladder, kidney, urinary & $78(0,0,0)$ & $310(1,0,1)$ & $450(3,1,3)$ & $315(1,1,2)$ & $240(0,0,0)$ & - \\
\hline \multirow[t]{4}{*}{$10-49$} & Liver & $5(0)$ & $228(0)$ & $340(5)$ & $269(1)$ & $200(2)$ & $1042(8)$ \\
\hline & Lung & $5(0)$ & $224(0)$ & $332(4)$ & $262(3)$ & 191(1) & $1014(8)$ \\
\hline & Bladder & $5(0)$ & $228(1)$ & $340(0)$ & $269(1)$ & $200(1)$ & $1042(3)$ \\
\hline & Bladder, kidney, urinary & $5(0,0,0)$ & $228(1,0,1)$ & $340(0,0,0)$ & $269(1,0,1)$ & $200(1,0,1)$ & - \\
\hline \multirow[t]{4}{*}{$50-99$} & Liver & $1(0)$ & $108(0)$ & $170(7)$ & $106(0)$ & $78(1)$ & $463(8)$ \\
\hline & Lung & $1(0)$ & $106(0)$ & $166(3)$ & $103(0)$ & $75(1)$ & $451(4)$ \\
\hline & Bladder & $1(0)$ & $108(1)$ & $170(0)$ & $106(0)$ & $78(0)$ & $463(1)$ \\
\hline & Bladder, kidney, urinary & $1(0,0,0)$ & $108(1,0,1)$ & $170(0,0,0)$ & $106(0,0,0)$ & $78(0,0,0)$ & - \\
\hline \multirow[t]{4}{*}{$100-149$} & Liver & $3(0)$ & $66(1)$ & $96(0)$ & $73(0)$ & $39(1)$ & $277(2)$ \\
\hline & Lung & $3(0)$ & $65(2)$ & $93(0)$ & $71(0)$ & $37(2)$ & $269(4)$ \\
\hline & Bladder & $3(0)$ & $66(0)$ & $96(0)$ & $73(1)$ & $39(2)$ & $277(3)$ \\
\hline & Bladder, kidney, urinary & $3(0,0,0)$ & $66(0,0,0)$ & $96(0,1,1)$ & $73(1,1,1)$ & $39(2,1,2)$ & - \\
\hline \multirow[t]{4}{*}{ 150-299 } & Liver & $10(0)$ & $49(0)$ & $64(0)$ & $57(0)$ & $40(0)$ & $220(0)$ \\
\hline & Lung & $10(0)$ & $49(0)$ & $62(1)$ & $56(0)$ & $36(1)$ & $213(2)$ \\
\hline & Bladder & $10(0)$ & $49(0)$ & $64(0)$ & $57(0)$ & $40(1)$ & $220(1)$ \\
\hline & Bladder, kidney, urinary & $10(0,0,0)$ & $49(0,0,0)$ & $64(0,0,0)$ & $57(0,0,0)$ & $40(1,0,1)$ & - \\
\hline \multirow[t]{4}{*}{$300-599$} & Liver & $7(0)$ & $68(1)$ & $119(1)$ & $87(0)$ & $48(0)$ & $329(2)$ \\
\hline & Lung & $7(0)$ & $65(0)$ & $115(2)$ & $85(2)$ & $45(0)$ & $317(4)$ \\
\hline & Bladder & $7(0)$ & $68(0)$ & $119(2)$ & $87(0)$ & $48(0)$ & $329(2)$ \\
\hline & Bladder, kidney, urinary & $7(0,0,0)$ & $68(0,1,1)$ & $119(2,3,5)$ & $87(0,1,1)$ & $48(0,1,0)$ & - \\
\hline \multirow[t]{4}{*}{$>600$} & Liver & $77(0)$ & $165(1)$ & $162(0)$ & $71(0)$ & $41(0)$ & $516(1)$ \\
\hline & Lung & $77(0)$ & $165(4)$ & $162(2)$ & $71(2)$ & $40(0)$ & $515(8)$ \\
\hline & Bladder & $77(2)$ & $165(1)$ & $162(6)$ & $71(3)$ & $41(1)$ & $516(13)$ \\
\hline & Bladder, kidney, urinary & $77(2,1,2)$ & $165(1,1,2)$ & $162(6,3,9)$ & $71(3,2,4)$ & $41(1,0,1)$ & - \\
\hline
\end{tabular}

a Observed number (cancer number).

b Excluding cigarette smokers.

whereas the methylation of As(III) takes place mainly in the liver and kidney according to Michaelis-Menten kinetics [13,15].

Mann et al. [17] suggested that the reduction of $\mathrm{As}(\mathrm{V})$ to $\mathrm{As}(\mathrm{III})$ can be modeled as a first-order oxidation/reduction reaction. The dynamic behavior of PK and metabolic processes in the PBPK model can be described by a set of first-order differential equations (see Appendix A for detail). The physiological parameters, metabolic constants, tissue/blood partition coefficients, and biochemical parameters are listed in Table A1 in Appendix A. We employed the MATLAB ${ }^{\circledR}$ software (The Mathworks Inc., MA, USA) to perform the PBPK simulations.

\subsection{Reference arsenic guideline and risk estimates}

We transformed arsenic exposure-response relationship into internal dose-based response function by incorporating PBPK model into Weibull model to account for the variability of risk estimates and reference arsenic guideline based on drinking water uptake rate distribution. To explicitly quantify the uncertainty/variability of drinking water data, a Monte Carlo simulation was performed with 10,000 iterations (stability condition) to obtain the $95 \%$ confidence interval (CI). The Monte Carlo simulation is implemented by using the Crystal Ball software (Version 2000.2, Decisioneering Inc., Denver, CO, USA). The $\chi^{2}$ and Kolmogorov-Smirnov (K-S) statistics were used to optimize the goodness-of-fit of distribution. Result shows that the selected lognormal distribution had the optimal K-S and $\chi^{2}$ goodness-of-fit for drinking water uptake rate.

The USEPA suggested point-of-departure analysis for cancer risk assessment is to estimate a point on the exposure response curve within the observed range of the data and then extrapolate linearly to lower dose [22,23]. Morales et al. [24] suggested that the use of $1 \%$ and $5 \%$ excess risks ( $\Delta \mathrm{ED}_{01}$ and $\Delta \mathrm{ED}_{05}$, respectively) for the point-of-departure analysis for cancer risk assessment suggested by USEPA [23] are better than that of $10 \%$ excess risk $\left(\Delta \mathrm{ED}_{10}\right)$ because an excess risk of $10 \%$ is relatively large and happens only at relative high doses in epidemiological studies. Morales et al. [24] pointed out that traditionally employed unit excess lifetime risk of $10^{-6}$ is probably unreliable for epidemiological data where exposure is not typically measured accurately enough to extrapolate to such low risk levels. Hence, we use $0.01 \%$ excess risk $\left(\Delta \mathrm{ED}_{0.01}\right)$ and $\triangle E D_{01}$ point-of-departure to quantify the risk and performed excess cancer risk assessment by the Monte Carlo simulation technique.

\section{Results}

\subsection{Fitting Weibull model to arsenic epidemiological data}

Weibull dose-response function (Eq. (3)) was best fitted to cumulative incidence ratios calculated from Tables 1 and 2 to obtain the optimal fitted parameters $k_{0}, k_{1}, k_{2}$, and $k_{3}$ for lung, liver, and bladder cancers for each gender (Table 3 ). We estimated Weibull dose response function for the background incidence of internal cancers and for the total incidence at a given arsenic concentration. A comparison population defining unexposed internal mortality rates was used as our background incidence of internal cancers, in which the internal cancer mortality data were collected from death certificates of residents of 42 villages during 1973-1986 in Taiwan [24]. We further defined $\Delta P \equiv P(t, C)-P(t, 0)$ to 


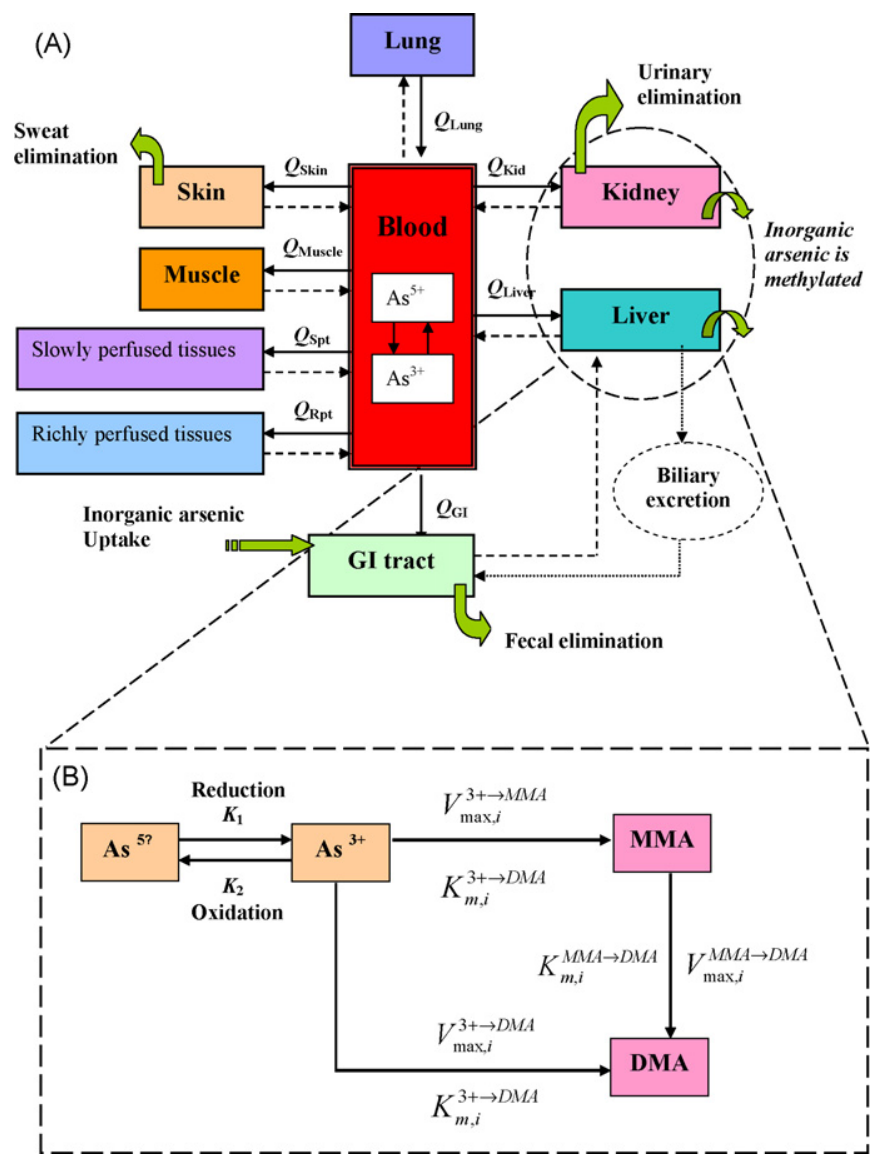

Fig. 2. Schematic of the proposed PBPK model showing (A) target tissue compartments interconnected by blood flow and (B) biotransformation of arsenic showing oxidation/reduction of inorganic arsenic and methylation of As(III) in kidney and liver. be the background-adjusted cumulative incidence ratio of internal cancers.

Our results indicate that bladder cancer has the highest $r^{2}$ values $(>0.85$ ) for all genders than those of lung (nearly 0.6 ) and liver $(<0.5)$ cancers, respectively (Fig. $3 \mathrm{~A}$ and B). For bladder cancer, higher $r^{2}$ values reveal a significant association of cumulative incidence ratios with arsenic concentration and age (the duration of water consumption) (male $r^{2}=0.86$ and female $r^{2}=0.87$ ). Furthermore, the Weibull dose-response surface for bladder cancer also presented in Fig. 4 and the cumulative incidence ratio was positive proportion of arsenic concentration in drinking water and age. Specifically for male, age has notably influence than arsenic concentration $\left(k_{1}=k_{2}=1.13\right)$ comparing to female $\left(k_{1}=1.36\right.$ and $\left.k_{2}=0.6\right)$ (Table 3 and Fig. $3 \mathrm{~A}$ and $\mathrm{B}$ ).

For lung cancer, average $r^{2}$ value is nearly 0.6 (male $r^{2}=0.67$ and female $r^{2}=0.58$ ), indicating that arsenic exposure concentration is not the only influence factors for lung cancer incidence. In the present study, the fitting of Weibull dose response model for lung cancer could not be implemented if we did not exclude the smoking population, implicating the cigarette smoking has significant effect on the arsenic-lung cancer association [25]. On the other hand, for liver cancer, the correlation of liver incidence between arsenic exposure concentration and age is not significant (male $r^{2}=0.45$ and female $r^{2}=0.41$ ).

\subsection{Variation analysis of arsenic concentration in PBPK model}

We used the present PBPK model to depict the relationship between drinking water uptake rate and arsenic species in blood. The percentile estimates of drinking water of $2.5,25,50,75$, and $97.5 \%$ to be $1.08,2.59,3.29,4.17$, and $6.52 \mathrm{Ld}^{-1}$ based on male body weight of $60 \mathrm{~kg}$. Our results indicate that $\mathrm{As}(\mathrm{V}), \mathrm{As}(\mathrm{III})$, and MMA levels in the blood increase with the increasing drinking water uptake rate (inorganic arsenic increasing from 12 to $25 \%$ expressed as ratio of arsenic species to total arsenic contents), whereas DMA\% level in blood decreases notably with increasing water uptake (from 79 to $62 \%$ ) based on water arsenic concentration of $50 \mu \mathrm{g} \mathrm{L}^{-1}$ (Fig. 3C). Simulation result from our life-stage-based PBPK model reveals that children (body weight is nearly $20 \mathrm{~kg}$ )

Table 3

Gender- and cancer-specific best fitted parameters in Weibull dose-response function $\left(P(t, C)=1-\exp \left(-\left(k_{0} C^{k 1}+k_{3}\right) t^{k 2}\right)\right)$

\begin{tabular}{|c|c|c|c|c|c|}
\hline & \multicolumn{5}{|l|}{ Best fitted parameters } \\
\hline & $k_{0}$ & $k_{1}$ & $k_{2}$ & $k_{3}$ & $r^{2}$ \\
\hline \multicolumn{6}{|l|}{ Male } \\
\hline \multicolumn{6}{|l|}{ Cancer } \\
\hline Lung $^{a}$ & $1.07 \times 10^{-7 b}\left((0-1.17) \times 10^{-6}\right)$ & $0.7(0-2.11)$ & $1.46(0.37-2.55)$ & $6.25 \times 10^{-6}\left((0-3.49) \times 10^{-5}\right)$ & 0.67 \\
\hline Liver $^{\mathrm{c}}$ & $5.24 \times 10^{-7}\left((0-5.00) \times 10^{-6}\right)$ & $0.823(0-2.01)$ & $1.21(0.33-2.09)$ & $6.01 \times 10^{-5}\left((0-2.82) \times 10^{-4}\right)$ & 0.45 \\
\hline Bladder $^{c}$ & $1.92 \times 10^{-7}\left((0-8.29) \times 10^{-7}\right)$ & $1.13(0.73-1.54)$ & $1.13(0.66-1.61)$ & $4.38 \times 10^{-9}\left((0-2.67) \times 10^{-5}\right)$ & 0.86 \\
\hline Bladder, kidney, urinary & $2.13 \times 10^{-7}\left((0-1.01) \times 10^{-6}\right)$ & $1.21(0.74-1.69)$ & $1.28(0.74-1.73)$ & $1.64 \times 10^{-9}\left((0-5.77) \times 10^{-5}\right)$ & 0.86 \\
\hline Bladder $^{\mathrm{d}}$ & $5.76 \times 10^{-7}\left((0-2.19) \times 10^{-6}\right)$ & $1.13(0.76-1.51)$ & $1.13(0.69-1.58)$ & $1.97 \times 10^{-9}\left((0-2.56) \times 10^{-5}\right)$ & 0.89 \\
\hline \multicolumn{6}{|l|}{ Female } \\
\hline Lunga & $8.72 \times 10^{-8}\left((0-9.73) \times 10^{-7}\right)$ & $0.83(0-2.26)$ & $1.45(0.65-2.26)$ & $1.45 \times 10^{-5}\left((0-6.40) \times 10^{-5}\right)$ & 0.58 \\
\hline Liver $^{c}$ & $1.50 \times 10^{-5}\left((0-8.90) \times 10^{-5}\right)$ & $0.14(0-0.43)$ & $1.09(0-2.2)$ & $1.13 \times 10^{-5}\left((0-6.74) \times 10^{-5}\right)$ & 0.41 \\
\hline Bladder $^{\mathrm{c}}$ & $2.02 \times 10^{-7}\left((0-1.28) \times 10^{-6}\right)$ & $1.36(0.63-2.08)$ & $0.6(0.04-1.16)$ & $1.03 \times 10^{-4}\left((0-1.76) \times 10^{-3}\right)$ & 0.87 \\
\hline Bladder, kidney, urinary & $3.38 \times 10^{-8}\left((0-2.43) \times 10^{-7}\right)$ & $1.78(0.89-2.67)$ & $0.67(0.20-1.15)$ & $5.03 \times 10^{-4}\left((0-1.55) \times 10^{-3}\right)$ & 0.84 \\
\hline
\end{tabular}

a Excluding smoking population.

b Best fitting value with $95 \% \mathrm{CI}$ shown in parenthesis.

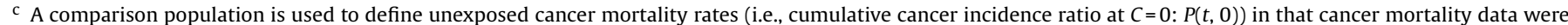
collected from death certificates of residents of 42 villages during 1973-1986 in Taiwan [24].

d Estimated from PBPK model calculated kidney dose associated with Weibull model fitted bladder incidence ratio. 

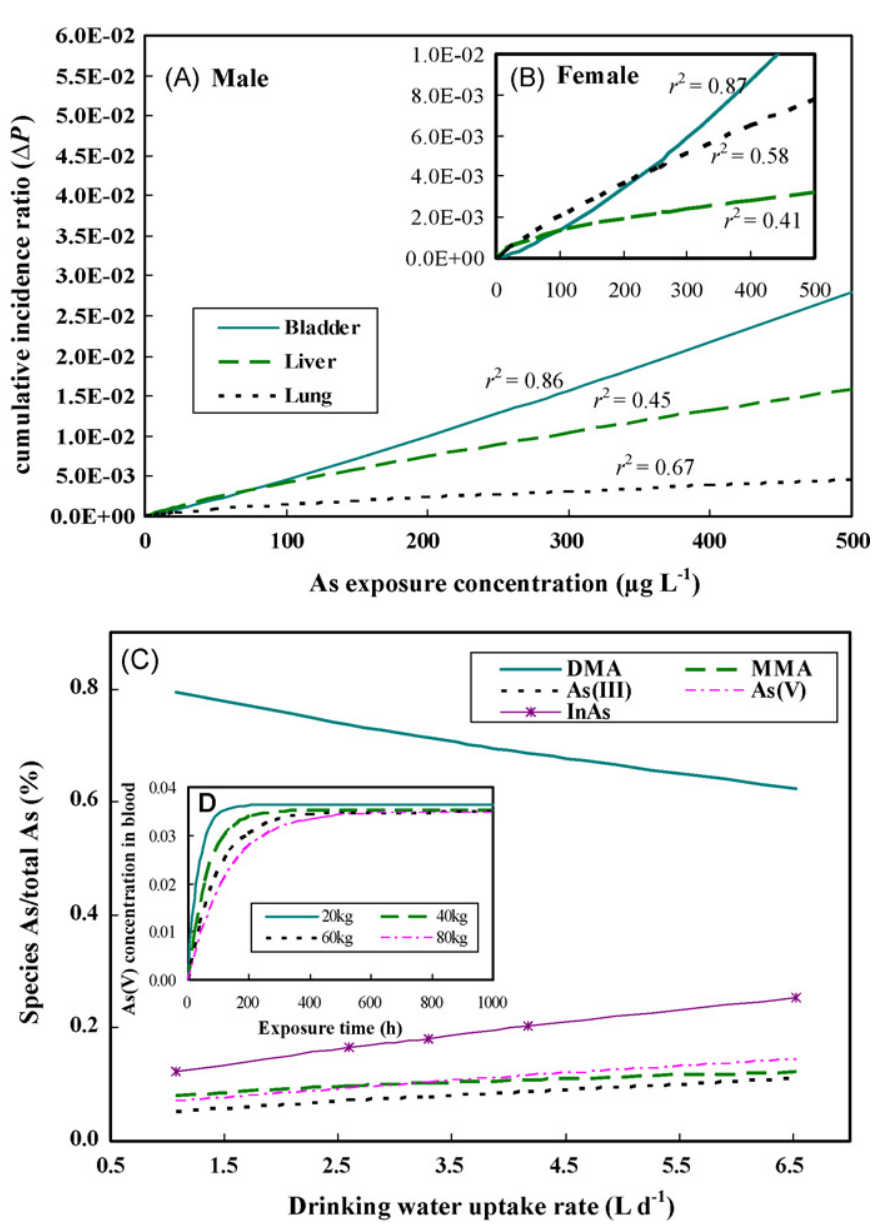

Fig. 3. Weibull dose-response function predicted background-adjusted cumulative incidence ratios as a function of arsenic exposure concentrations ranging from $0-500 \mu \mathrm{g} \mathrm{L}^{-1}$ for (A) male and (B) female bladder, liver, and lung cancers. (C) Relationship between arsenic species/total arsenic ratios and drinking water uptake rates ranging from 1.08 to $6.25 \mathrm{Ld}^{-1}$. (D) $\mathrm{As}(\mathrm{V})$ concentrations in blood varying with exposure times for body weights ranging from 20 to $80 \mathrm{~kg}$ based on the long-term exposure to drinking water arsenic content of $50 \mu \mathrm{g} \mathrm{L}^{-1}$ with a water uptake rate of $3.29 \mathrm{Ld}^{-1}$.

are relatively more sensitive to arsenic exposure during short-term period at both the same arsenic levels and drinking water uptake rate in the blood than those of adults (body weights ranging from 60 to $80 \mathrm{~kg}$ ) (Fig. 3D).

\subsection{Reference arsenic guideline estimates}

Fitting Weibull models to specific cancer cumulative incidence ratios reveals that the risk of male bladder cancer incidence is the highest for the study participants of residents in arseniasisendemic areas $\left(r^{2}=0.86\right)$. Therefore, based on male bladder cancer as our index cancer, we estimate the drinking water arsenic concentration based on Fig. 4 with excess risk of $10^{-4}$ suggested by USEPA and a median daily drinking water uptake rate of $3.29 \mathrm{Ld}^{-1}$ (Fig. 5B) for lifetime exposure duration of 75 years and an average male body weight of $60 \mathrm{~kg}$.

Our result shows that the water inorganic arsenic guideline is estimated to be $3.4 \mu \mathrm{g} \mathrm{L}^{-1}$ based on a $0.01 \%$ excess risk $\left(\Delta \mathrm{ED}_{0.01}\right)$. We further used $1 \%$ excess dose $\left(\Delta \mathrm{ED}_{01}\right)$ to linearly extrapolate to the $\Delta \mathrm{ED}_{0.01}$ point at low concentration ranges, resulting in a water inorganic arsenic concentration of $2 \mu \mathrm{g} \mathrm{L}^{-1}$. This result indicates that Weibull dose-response function for male bladder cancer demonstrates a nearly linear with slightly concave characteristic at

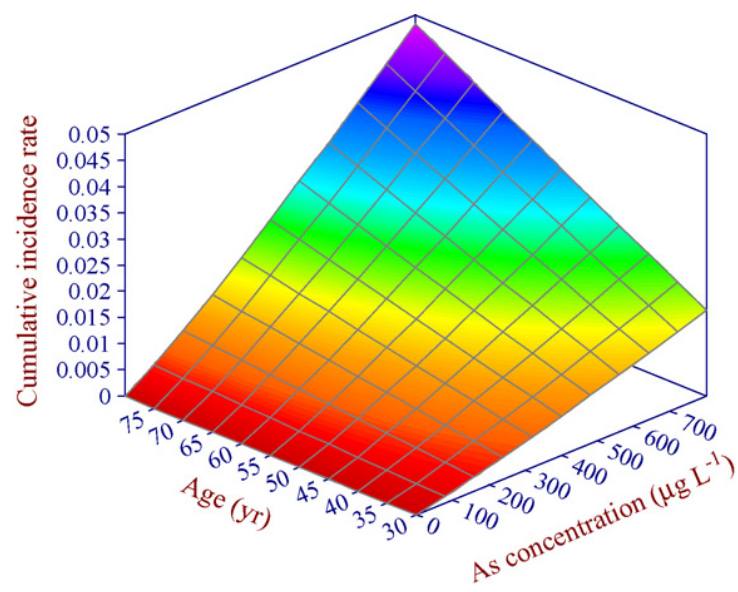

Fig. 4. Best-fitted Weibull model-based dose-response surfaces reflecting an agespecific relationship between cumulative incidence ratio and arsenic exposure concentrations for male bladder cancer.

low arsenic concentration ranges. Therefore, based on male bladder cancer as the index, internal cancer with an excess lifetime risk of $10^{-4}$ to obtain the drinking water arsenic concentration of $3.4 \mu \mathrm{gL}^{-1}\left(r^{2}>0.8\right)$ can be reasonably adopted as a reference guideline value for drinking water in the present study.
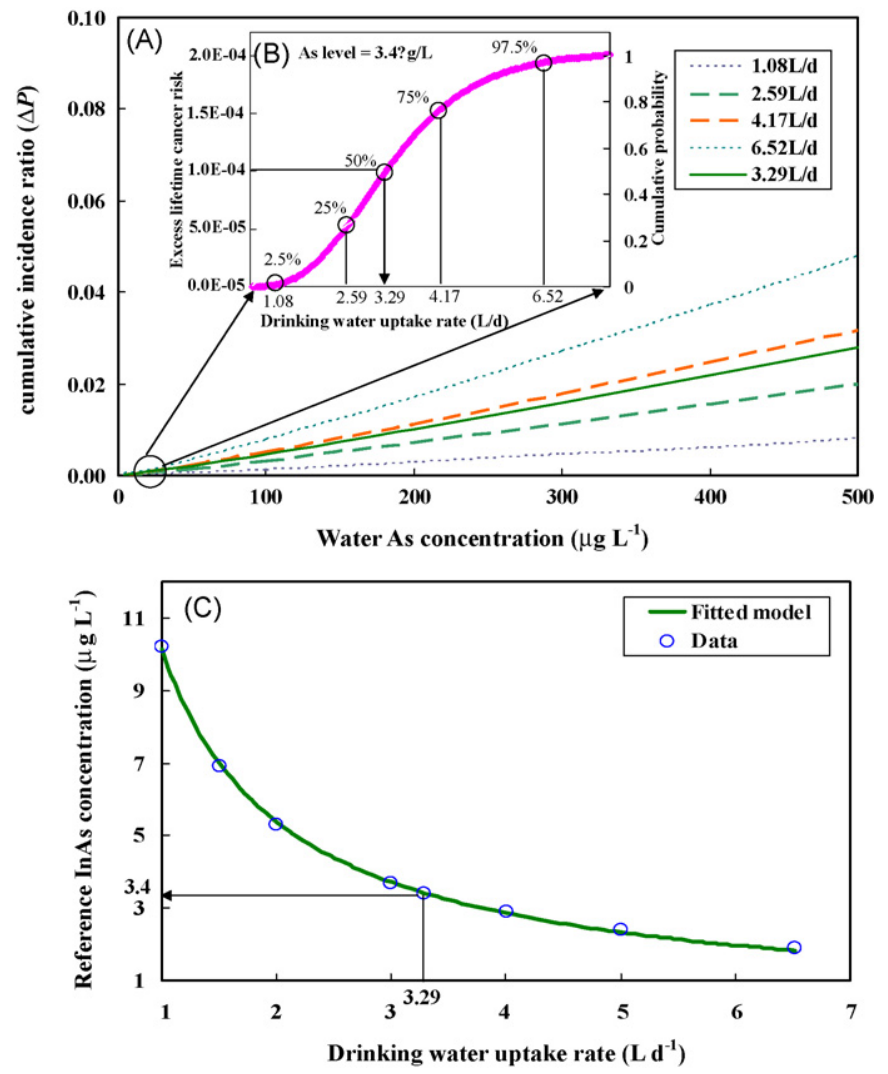

Fig. 5. (A) Relationship between cumulative incidence ratios and water arsenic concentration varied with different drinking water uptake rates ranging from 1.08 to $6.52 \mathrm{Ld}^{-1}$. (B) Excess lifetime cancer risk estimates varied with different drinking water uptake rates based on the unit risk of $1.0 \times 10^{-4}$ when drinking water arsenic concentration is $3.4 \mu \mathrm{g} \mathrm{L}^{-1}$. (C) Estimated reference drinking water inorganic arsenic guideline as a function of drinking water uptake rates for male 70 years with an average body weight of $60 \mathrm{~kg}$ in that the fitted power relation $y=10.125 x^{-0.913}$ is also shown. 


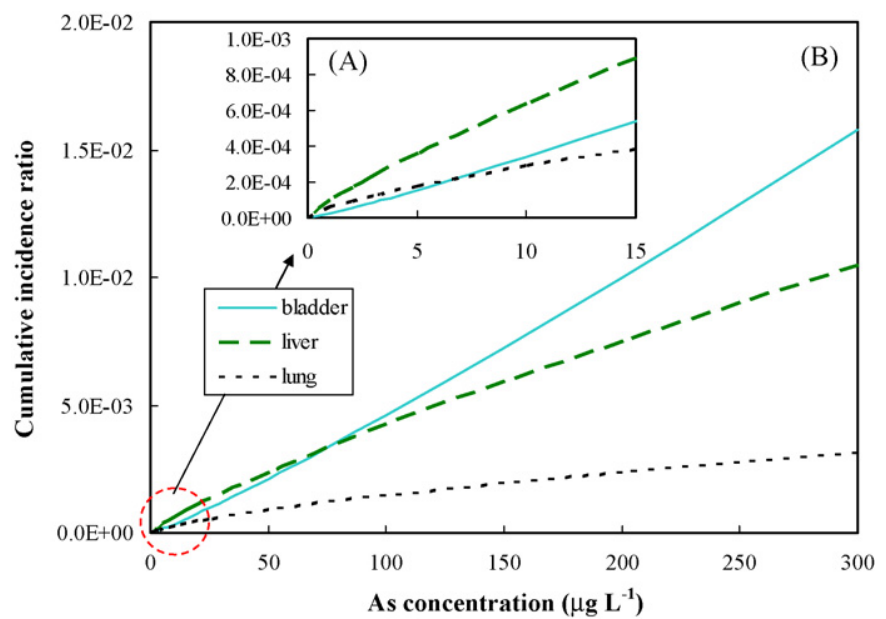

Fig. 6. The characteristics of the Weibull dose-response curves for male-specific internal cancer in arsenic exposure concentration ranges of (A) $0-15 \mu \mathrm{g} \mathrm{L}^{-1}$ and (B) $0-300 \mu \mathrm{g} \mathrm{L}^{-1}$.

\subsection{Risk estimates}

We adopted male bladder cancer as our index cancer to estimate reference arsenic guideline. We used internal arsenic levels calculated from the PBPK model to reconstruct an internal dose-response relationship followed Weibull model and referred to as the Weibull $\mathrm{in}_{\text {in }}$ model. We incorporated the PBPK model into drinking water uptake rate distribution to estimate the internal arsenic levels in specific tissue/organ. The results indicate that cumulative bladder cancer incidence ratios or excess lifetime cancer risks range from $2.84 \times 10^{-5}$ to $1.96 \times 10^{-4}$ varied with drinking water uptake rates ranging from $1.08-6.52 \mathrm{Ld}^{-1}$ (Fig. 5A and B).

The PBPK model associated with drinking water uptake rate distribution was further employed to estimate the range values of reference arsenic concentration. The result indicates that reference arsenic concentrations are estimated to be 5.3, 3.7, and $2.9 \mu \mathrm{g} \mathrm{L}^{-1}$, respectively, based on the drinking water uptake rates of 2,3 , and $4 \mathrm{Ld}^{-1}$ associated with the PBPK model-derived kidney inorganic arsenic level of $1.17 \times 10^{-3} \mu \mathrm{gg}^{-1}$ wet weight with an excess unit risk of $10^{-4}$ (Fig. 5C). A parsimonious power model $\left(y=10.125 x^{-0.913}, r^{2}=0.99, p<0.01\right)$ was best describes the relationship between suggested reference arsenic concentrations (ranged from 10.2 to $1.9 \mu \mathrm{g} \mathrm{L}^{-1}$ ) and drinking water uptake rates (ranged from 1.08 to $6.52 \mathrm{Ld}^{-1}$ ) (Fig. $5 \mathrm{C}$ ).

\section{Discussion}

\subsection{Weibull model risk analysis}

The cumulative incidence ratios of male internal cancers revealed through the Weibull model-based arsenic epidemiology follow the order of bladder $>$ lung $>$ liver cancers. Theoretically, from the viewpoint of reference arsenic concentrations the order shall follow liver $>$ lung $>$ bladder cancers. Yet we divided the arsenic exposure concentration ranges into $0-15$ and $0-300 \mu \mathrm{g} \mathrm{L}^{-1}$ to evaluate the cumulative incidence ratios of male internal cancers based on the Weibull dose-response function. The results reveal that at low arsenic concentration range $\left(0-15 \mu \mathrm{g} \mathrm{L}^{-1}\right)$ the cumulative incidence ratios of liver and lung cancers are higher than that of bladder cancer, whereas linearity exists in the high arsenic concentration range (0-300 $\left.\mu \mathrm{g} \mathrm{L}^{-1}\right)$ (Fig. $6 \mathrm{~A}$ and $\mathrm{B}$ ).

The reason for that may due in part to the epidemiological studies involving largely unknown confounders resulted from the long-term arsenic exposure investigations at external environmental conditions (average exposure period $>20$ years) and not only experienced at the laboratory settings. Hence, low arsenic concentration induced adverse health effects are easily affected by non-arsenic induced exposure factors that result in an unavoidable variability while fitting Weibull dose-response function to epidemiological data in low concentration ranges. Due to the relative low $r^{2}$ values (involving largely unknown confounders) for liver and lung cancers, we suggested that $\Delta \mathrm{ED}_{01}$ or $\Delta \mathrm{ED}_{05}$ may be used as the point-of-departure to linearly extrapolate to $\Delta \mathrm{ED}_{0.01}$ point to obtain the excess lifetime cancer risk for avoiding the largely unknown potential influence factors.

\subsection{Reference arsenic guideline analysis}

Nation Research Council (NRC) indicated that male intakes $3 \mu \mathrm{g} \mathrm{L}^{-1}$ of arsenic resulting in an excess lifetime bladder cancer risk of $2 \times 10^{-4}$ that is closed to our estimate. The safe drinking water arsenic standard is recommended to be $10 \mu \mathrm{g} \mathrm{L}^{-1}$ in Taiwan region (EPAROC, 2005; http://w3.epa.gov.tw/epalaw/docfile/090040.pdf), whereas USEPA in 2000 had suggested the guideline value may lower to $5 \mu \mathrm{g} \mathrm{L}^{-1}$ to meet public health concerns $[4,9]$ and that was also closed to our proposed guideline estimate of $3.4 \mu \mathrm{g} \mathrm{L}^{-1}$.

NRC [9] suggested the drinking water uptake rate for Taiwanese male and female to be 3.5 and $2 \mathrm{Ld}^{-1}$, respectively. However, NRC has also adjusted the estimates respectively to 4.5 and $3 \mathrm{Ld}^{-1}$ to take into account the cooking water ingestion rate of nearly $1 \mathrm{Ld}^{-1}$. Theoretically, there is somewhat a correlation between body weight and drink water uptake rate. Generally, average body weight of American (86.7 kg in 1999-2002) is much higher than that of Taiwanese $(60 \mathrm{~kg}$ in 2002). A Monte Carlo technique was used to estimate the Taiwanese average drinking water uptake rate as $3.29 \mathrm{Ld}^{-1}$ that is more reasonable than those of the estimates of $4.5 \mathrm{Ld}^{-1}$ suggested by NRC and of traditionally assumed value of $2 \mathrm{~L} / \mathrm{d}$ in addition to $1 \mathrm{Ld}^{-1}$ of cooking water ingestion rate.

USEPA [10] reported that the average community drinking water uptake rate is $1 \mathrm{Ld}^{-1}$ and average total drinking water uptake rate is $1.2 \mathrm{Ld}^{-1}$ in 1994-1996 with the 90\%-tile estimates of 2.1 and $2.3 \mathrm{Ld}^{-1}$, respectively. Based on our proposed Weibull modelbased arsenic epidemiological with PBPK model framework, the reference arsenic concentration was estimated to be $5.3 \mu \mathrm{g} \mathrm{L}^{-1}$ for people lived in Taiwan cities with a drinking water uptake rate of $2 \mathrm{Ld}^{-1}$ (90\%-tile estimate) (Fig. 5C). On the other hand, the reference arsenic concentration is estimated to be $10.2 \mu \mathrm{g} \mathrm{L}^{-1}$ for American people with an average drinking water uptake rate of $1 \mathrm{Ld}^{-1}$. Those estimates meet reasonable well with the safe drinking water arsenic guideline of $10 \mu \mathrm{g} \mathrm{L}^{-1}$ recommended by WHO and of $5 \mu \mathrm{g} \mathrm{L}^{-1}$ in Federal Register proposed by USEPA [10].

\subsection{Implications}

We expected that our present Weibull dose-response model could be applied to predict and evaluate health effects in Bangladesh or west Bengal where comprehensive studies of arsenic-induced cancers have not been conducted to date. An analysis of the implications of arsenic-induced cancer risks in arseniasis-endemic areas would be more complex and would include consideration of impacts on regionally specific information on social, demographic, and economic trends. Moreover, the arsenic-induced cancer risks plausible concurrent with human-induced changes. These human-driven transitions in arseniasis-endemic areas (e.g., cigarette smoking) are likely to have a larger impact on risk profiling than arsenic-only-induced transitions [25]. Although our information may not be able to provide an unambiguous definition of reference arsenic guideline and risk 
estimates, it may help to inform public and regulatory authorities on discussions of risk management and communication by drawing attention to the worldwide arsenic issues.

Looking forward, we proposed that this Weibull model-based arsenic epidemiology and PBPK approach, which amounts to arsenic-induced internal cancer risk profiling associated with a proposed reference drinking water arsenic guideline, might provide the basis of a future population-based risk management strategy. Furthermore, this approach should have certain advantages over methods for dose response profile selection that are dependent on the use of arsenic epidemiological data to characterize particular aspects of risk analysis. A further inherent benefit of the WeibullPBPK approach is to provide interplay among system approach, regulatory processes, and risk management. The main potential application we envisage for Weibull-PBPK approach is with respect to human health, and there is clearly a need for further development and to investigate how well the approach can be transferred from Taiwan to Bangladesh or West Bengal populations, for whom much greater carcinogenic and environmental variation would be expected.

Recent developments in data analysis should assist safe drinking water arsenic standard establishment and biomarkers identification of arsenic-induced health hazards [3]. Metabolite profiling of fluids in PBPK model other than urine and bile, such as blood and fecal excretion, should provide additional information. In principle, by using this methodology, the variability in risk estimates in low arsenic concentration ranges could potentially be avoided and the suggested reference drinking water arsenic guideline could be more effectively estimated according to the robustness of the Weibull model and proposed PBPK characteristics. We envisage that optimal quantification of internal cancer risks from arsenic in drinking water may eventually involve a variety of dose response-prediction approaches, including both PBPK and physiologically based pharmadynamics (PBPD).

However, by linking Weibull model-based arsenic epidemiology and life-stage PBPK has an important theoretical advantage over traditional models in that it can potentially take account of both physiological and environmental factors affecting arsenic-induced adverse health responses. Furthermore, although the proposed framework would normally relate to predict reference drinking water arsenic concentration and the likelihood of risk estimates, we envisage that similar methodology could be applied to predict potential population-level long-term low dose cancer risk responses to broader medical, dietary, microbiological or physiological challenges.

\section{Appendix A. Equations and input parameters used in the PBPK model}

See Table A1. 
Table A1

Input parameters used in the PBPK model.

\begin{tabular}{|c|c|c|c|c|c|c|c|c|c|c|c|c|}
\hline \multirow[t]{2}{*}{ Tissue } & \multirow[t]{2}{*}{$\begin{array}{l}\text { Blood flow fraction } \\
\left(F_{i}\right)(\%)^{\mathrm{a}}\end{array}$} & \multirow[t]{2}{*}{$\begin{array}{l}\text { \% of body weight } \\
\left(W_{i}\right)(\%)^{\mathrm{b}}\end{array}$} & \multirow[t]{2}{*}{$\begin{array}{l}\text { Density }\left(D_{i}\right) \\
\left(\mathrm{kg} \mathrm{L}^{-1}\right)^{\mathrm{b}}\end{array}$} & \multirow[t]{2}{*}{$\begin{array}{l}\text { Water elimination } \\
\text { amount }(\mathrm{mL})^{c}\end{array}$} & \multirow{2}{*}{$\begin{array}{l}\% \text { total water } \\
\text { elimination } \\
\text { amount }(\%)^{c}\end{array}$} & \multicolumn{4}{|c|}{$\begin{array}{l}\text { Species-specific tissue/blood } \\
\text { partition coefficient }\end{array}$} & \multicolumn{3}{|c|}{$\begin{array}{l}\text { Oxidation/reduction rate constant }\left(\mathrm{h}^{-1}\right)^{\mathrm{d}}(\text { reduction } \\
1.37 \text {, oxidation } 1.83) \text {, methylation affinity constants }\end{array}$} \\
\hline & & & & & & $\operatorname{As}(\mathrm{III})$ & $\operatorname{As}(\mathrm{V})$ & $\mathrm{MMA}(\mathrm{V})$ & $\operatorname{DMA}(\mathrm{V})$ & $\mathrm{As}(\mathrm{III}) \rightarrow \mathrm{MMA}(\mathrm{V})$ & $\mathrm{As}(\mathrm{III}) \rightarrow \mathrm{DMA}(\mathrm{V})$ & $\mathrm{MMA} \rightarrow \mathrm{DMA}(\mathrm{V})$ \\
\hline Lung & 100 & 1.7 & 1.05 & 300 & 12 & 4.15 & 4.15 & 1.8 & 2.075 & & & \\
\hline $\begin{array}{l}\text { Kidneys } \\
V_{\max }\left(\mu \mathrm{mol} \mathrm{h}^{-1}\right) \\
K_{\mathrm{m}}\left(\mu \mathrm{mol} \mathrm{L}^{-1}\right)\end{array}$ & 20 & 4.4 & 1.05 & 1500 & 60 & 4.15 & 4.15 & 1.8 & 2.075 & $\begin{array}{r}75 \\
100\end{array}$ & $\begin{array}{c}10.02 \\
100\end{array}$ & $\begin{array}{r}5 \\
100\end{array}$ \\
\hline $\begin{array}{l}\text { Skin (fat) } \\
\text { Sweat in consciousness } \\
\text { Sweat in unconsciousness } \\
\text { GI tract }\end{array}$ & 5 & 20 & 0.92 & $\begin{array}{l}400 \\
100 \\
200\end{array}$ & 20 & 2.5 & 2.5 & 1.25 & 1.25 & & & \\
\hline $\begin{array}{l}\text { Liver } \\
\qquad V_{\max }\left(\mu \mathrm{mol} \mathrm{h}^{-1}\right) \\
K_{\mathrm{m}}\left(\mu \mathrm{mol} \mathrm{L}^{-1}\right)\end{array}$ & 5 & 2.57 & 1.04 & & & & 5.3 & 5.3 & 2.35 & $\begin{array}{l}11.25 \\
100\end{array}$ & $\begin{array}{l}22.25 \\
100\end{array}$ & $\begin{array}{l}16.02 \\
100\end{array}$ \\
\hline $\begin{array}{l}\text { Muscle } \\
\text { Richly perfused tissues } \\
\text { Slowly perfused tissues }\end{array}$ & $\begin{array}{l}15 \\
27.5 \\
7.5\end{array}$ & $\begin{array}{c}40 \\
8.4 \\
20.93\end{array}$ & $\begin{array}{l}1.04 \\
1.03 \\
1.04\end{array}$ & & & $\begin{array}{l}2.6 \\
2.6 \\
0.3\end{array}$ & $\begin{array}{l}2.6 \\
2.6 \\
0.3\end{array}$ & $\begin{array}{l}1.8 \\
1.8 \\
0.3\end{array}$ & $\begin{array}{l}1.8 \\
1.8 \\
0.3\end{array}$ & & & \\
\hline Total & & & & 2500 & 100 & & & & & & & \\
\hline
\end{tabular}

Total

$\times \mathrm{BW}^{0.75}(\mathrm{~kg})$, blood flow rate in specific organ $\mathrm{Q}_{\mathrm{i}}=F_{i} \times \mathrm{Q}_{\mathrm{T}}$, and organ volume $V_{i}=\mathrm{BW} \times W_{i} / D_{i}[26,27]$

b Adpated from Hissink et al. [28] and Yu et al. [29].

c Adapted from Huang [30].

d Adapted from Mann et al. [16]

e Adapted from Yu [13,15]. 
C.-M. Liao et al. / Journal of Hazardous Materials 165 (2009) 652-663

661

1. Lung

As( III)

$\operatorname{As}(\mathrm{V})$

MIA

DNA

2. Kidney

As( III)

$\operatorname{As}(\mathrm{V})$

MM

DNA

3. Skin

As( III)

$\operatorname{As}(\mathrm{V})$

MIA

DNA

4. GI tract

As( III)

$\mathrm{As}(\mathrm{V})$

MIA

DNA

5. Liver

As( III)

$\operatorname{As}(\mathrm{V})$

MIA

DNA

6. Blood

As( III)

$\operatorname{As}(\mathrm{V})$

$$
\begin{aligned}
& \frac{d A_{\text {Lung }}^{3+}}{d t}=Q_{\text {Lung }} \times\left(C_{a}^{3+}-\frac{C_{\text {Lung }}^{3+}}{P_{\text {Lung }}^{3+}}\right)+\left(K_{1} \times C_{\text {Lung }}^{5+}-K_{2} \times C_{\text {Lung }}^{\text {III }}\right) \times V_{\text {Lung }} \\
& \frac{d A_{\text {Lung }}^{5+}}{d t}=Q_{\text {Lung }} \times\left(C_{a}^{5+}-\frac{C_{\text {Lung }}^{5+}}{P_{\text {Lung }}^{5+}}\right)-\left(K_{1} \times C_{\text {Lung }}^{5+}-K_{2} \times C_{\text {Lung }}^{5+}\right) \times V_{\text {Lung }}
\end{aligned}
$$$$
\frac{d A_{\text {Lung }}^{\text {MIA }}}{d t}=Q_{\text {Lung }} \times\left(C_{a}^{M M A}-\frac{C_{\text {Lung }}^{\text {MIA }}}{P_{\text {Lung }}^{M M A}}\right)
$$

$$
\frac{d A_{\text {Lung }}^{\text {DNA }}}{d t}=Q_{\text {Lung }} \times\left(C_{a}^{D M A}-\frac{C_{\text {Lung }}^{\text {DNA }}}{P_{\text {Lung }}^{D \text { DA }}}\right)
$$

$$
\frac{d A_{\text {Kid }}^{3+}}{d t}=Q_{\text {Kid }} \times\left(C_{a}^{3+}-\frac{C_{\text {Kid }}^{3+}}{P_{\text {Kid }}^{3+}}\right)+\left(K_{1} \times C_{\text {Kid }}^{5+}-K_{2} \times C_{\text {Kid }}^{3+}\right) \times V_{\text {Kid }}-\frac{V_{\text {max, Kid }}^{3+\rightarrow M M A} \times C_{\text {Kid }}^{3+}}{K_{m, \text { Kid }}^{3+} \rightarrow \text { AMA }+C_{\text {Kid }}^{3+}}-\frac{V_{\text {max }, \text { Kid }}^{3+} \times C_{\text {Kid }}^{I I I}}{K_{m, \text { Kid }}^{3+} \rightarrow C_{\text {Kid }}}-W_{\text {day }}^{I I I} \times K_{\text {urine }} \times \frac{C_{\text {Kid }}^{3+}}{P_{\text {Kid }}^{3+}}
$$

$\frac{d A_{\text {Kid }}^{5+}}{d t}=Q_{\text {Kid }} \times\left(C_{a}^{5+}-\frac{C_{\text {Kid }}^{5+}}{P_{\text {Kid }}^{5+}}\right)-\left(K_{1} \times C_{\text {Kid }}^{5+}-K_{2} \times C_{\text {Kid }}^{3+}\right) \times V_{\text {Kid }}-W_{\text {day }} \times K_{\text {urine }} \times \frac{C_{\text {Kid }}^{5+}}{P_{\text {Kid }}^{5+}}$

$\frac{d A_{\text {Kid }}^{\text {MAI }}}{d t}=Q_{\text {Kid }} \times\left(C_{a}^{M M A}-\frac{C_{\text {Kid }}^{M M A}}{P_{\text {Kid }}^{M M A}}\right)+\frac{V_{\text {max, Kid }}^{3+\rightarrow M M A} \times C_{\text {Kid }}^{I I I}}{K_{m, \text { Kid }}^{3+\rightarrow M M A}+C_{\text {Kid }}^{I I I}}-\frac{V_{\text {max }, \text { Kid }}^{M M A} \times C_{\text {Kid }}^{M M A}}{K_{m, K i d}^{M M A D A}+C_{\text {Kid }}^{M M A}}-W_{\text {day }} \times K_{\text {urine }} \times \frac{C_{\text {Kid }}^{M M A}}{P_{\text {Kid }}^{M M A}}$

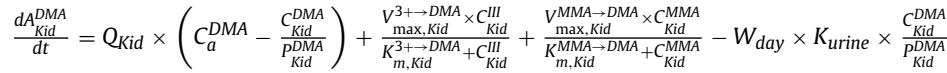

$\frac{d A_{\text {Skin }}^{3+}}{d t}=Q_{\text {Skin }} \times\left(C_{a}^{3+}-\frac{C_{\text {Skin }}^{3+}}{P_{\text {Skin }}^{3+}}\right)+\left(K_{1} \times C_{\text {Skin }}^{5+}-K_{2} \times C_{\text {Skin }}^{3+}\right) \times V_{\text {Skin }}-W_{\text {day }} \times K_{\text {Skin }} \times C_{\text {Skin }}^{3+}$

$\frac{d A_{\text {Skin }}^{5+}}{d t}=Q_{\text {Skin }} \times\left(C_{a}^{5+}-\frac{C_{\text {Skin }}^{5+}}{P_{\text {Skin }}^{5+}}\right)-\left(K_{1} \times C_{\text {Skin }}^{5+}-K_{2} \times C_{\text {Skin }}^{3+}\right) \times V_{\text {Skin }}-W_{\text {day }} \times K_{\text {Skin }} \times C_{\text {Skin }}^{5+}$

$\frac{d A_{\text {Skin }}^{M M A}}{d t}=Q_{S k i n} \times\left(C_{a}^{M M A}-\frac{C_{S k i n}^{M M A}}{P_{S k i n}^{M M A}}\right)-W_{\text {day }} \times K_{S k i n} \times C_{S k i n}^{M M A}$

$\frac{d A_{\text {Skin }}^{\text {DNA }}}{d t}=Q_{S k i n} \times\left(C_{a}^{D M A}-\frac{C_{\text {Skin }}^{\text {DNA }}}{P_{\text {Skin }}^{D M A}}\right)-W_{\text {day }} \times K_{\text {Skin }} \times C_{\text {Skin }}^{D M A}$

$\frac{d A_{G I}^{3+}}{d t}=Q_{G I} \times\left(C_{a}^{3+}-\frac{C_{G I}^{3+}}{P_{G I}^{3+}}\right)-Q_{G I} \times\left(\frac{C_{G I}^{3+}}{P_{G I}^{3+}}-\frac{C_{\text {Liver }}^{3+}}{P_{\text {Liver }}^{3+}}\right)+\left(K_{1} \times C_{G I}^{5+}-K_{2} \times C_{G I}^{3+}\right) \times V_{G I}-W_{\text {day }} \times K_{G I} \times C_{G I}^{3+}+K_{\text {uptake }}^{3+}$

$\frac{d A_{G I}^{5+}}{d t}=Q_{G I} \times\left(C_{a}^{5+}-\frac{C_{G I}^{5+}}{P_{G I}^{5+}}\right)-Q_{G I} \times\left(\frac{C_{G I}^{5+}}{P_{G I}^{5+}}-\frac{C_{\text {Liver }}^{5+}}{P_{\text {Liver }}^{5+}}\right)-\left(K_{1} \times C_{G I}^{5+}-K_{2} \times C_{G I}^{3+}\right) \times V_{G I}-W_{\text {day }} \times K_{G I} \times C_{G I}^{3+}+K_{\text {uptake }}^{5+}$

$\frac{d A_{G I}^{M M A}}{d t}=Q_{G I} \times\left(C_{a}^{M M A}-\frac{C_{G I}^{M M A}}{P_{G I}^{M M A}}\right)-Q_{G I} \times\left(\frac{C_{G I}^{M M A}}{P_{G I}^{M M A}}-\frac{C_{\text {Liver }}^{M M A}}{P_{\text {Liver }}^{M M A}}\right)-W_{\text {day }} \times K_{G I} \times C_{G I}^{M M A}$

$\frac{d A_{G I}^{D M A}}{d t}=Q_{G I} \times\left(C_{a}^{D M A}-\frac{C_{G I}^{D M A}}{P_{G I}^{D M A}}\right)-Q_{G I} \times\left(\frac{C_{G I}^{D M A}}{P_{G I}^{D M A}}-\frac{C_{\text {Liver }}^{D M A}}{P_{\text {Liver }}^{D M A}}\right)-W_{\text {day }} \times K_{G I} \times C_{G I}^{D M A}$

$\frac{d A_{\text {Liver }}^{3+}}{d t}=Q_{\text {Liver }} \times\left(C_{a}^{3+}-\frac{C_{\text {Liver }}^{3+}}{P_{\text {Liver }}^{3+}}\right)+Q_{G I} \times\left(\frac{C_{G I}^{3+}}{P_{G I}^{3+}}-\frac{C_{\text {Liver }}^{3+}}{P_{\text {Liver }}^{3+}}\right)+\left(K_{1} \times C_{\text {Liver }}^{5+}-K_{2} \times C_{\text {Liver }}^{3+}\right) \times V_{\text {Liver }}-W_{\text {Biliary }} \times C_{\text {Liver }}^{3+}-\frac{V_{\text {max }, \text { Liver }}^{3+} \times C_{\text {Liver }}^{3+}}{K_{\mathrm{m}, \text { Liver }}^{3+} \rightarrow C_{\text {Liver }}^{3+}}-\frac{V_{\text {max }, \text { Liver }}^{3+\rightarrow \text { DNA }} \times C_{\text {Liver }}^{\text {III }}}{K_{\mathrm{m}, \text { Liver }}^{3+} \rightarrow \text { DA }}+C_{\text {Liver }}^{I I I}$

$\frac{d A_{\text {Liver }}^{5+}}{d t}=Q_{\text {Liver }} \times\left(C_{a}^{5+}-\frac{C_{\text {Liver }}^{5+}}{P_{\text {Liver }}^{5+}}\right)+Q_{G I} \times\left(\frac{C_{G I}^{5+}}{P_{G I}^{5+}}-\frac{C_{\text {Liver }}^{5+}}{P_{\text {Liver }}^{5+}}\right)-\left(K_{1} \times C_{\text {Liver }}^{5+}-K_{2} \times C_{\text {Liver }}^{3+}\right) \times V_{\text {Liver }}-W_{\text {Biliary }} \times C_{\text {Liver }}^{5+}$

$\frac{d A_{\text {Liver }}^{M M A}}{d t}=Q_{\text {Liver }} \times\left(C_{a}^{M M A}-\frac{C_{\text {Live }}^{M M A}}{P_{\text {Liver }}^{M M A}}\right)+Q_{G I} \times\left(\frac{C_{G I}^{M M A}}{P_{G I}^{M M A}}-\frac{C_{\text {Liver }}^{M M A}}{P_{\text {Liver }}^{M M A}}\right)+\frac{V_{\max , \text { Liver }}^{3+\rightarrow M M A} \times C_{\text {liver }}^{\text {III }}}{K_{\mathrm{m}, \text { Liver }}^{3+M M A}+C_{\text {Liver }}^{\text {III }}}-\frac{V_{\max , \text { Liver }}^{M M A \rightarrow D M A} \times C_{\text {liver }}^{M M A}}{K_{\mathrm{m}, \text { Liver }}^{M M A}+C_{\text {Liver }}^{M M A}}-W_{\text {Biliary }} \times C_{\text {Liver }}^{M M A}$

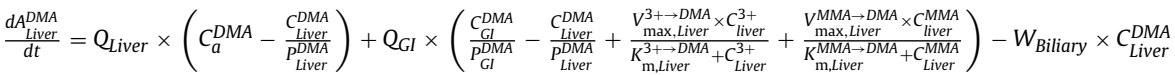

$\frac{d A_{a}^{3+}}{d t}=\left(\sum_{i=1}^{8} Q_{i} \times \frac{C_{i}^{3+}}{P_{i}^{3+}}-\sum_{i=1}^{8} Q_{i} \times C_{a}^{3+}\right)+\left(K_{1} \times C_{a}^{5+}-K_{2} \times C_{a}^{3+}\right) \times V_{a}$

$\frac{d A_{a}^{5+}}{d t}=\left(\sum_{i=1}^{8} Q_{i} \times \frac{C_{i}^{5+}}{P_{i}^{5+}}-\sum_{i=1}^{8} Q_{i} \times C_{a}^{5+}\right)-\left(K_{1} \times C_{a}^{5+}-K_{2} \times C_{a}^{3+}\right) \times V_{a}$ 
MMA

$$
\begin{aligned}
& \frac{d A_{a}^{\text {MMA }}}{d t}=\left(\sum_{i=1}^{8} Q_{i} \times \frac{C_{i}^{\text {MMA }}}{P_{i}^{\text {MMA }}}-\sum_{i=1}^{8} Q_{i} \times C_{a}^{\text {MMA }}\right) \\
& \frac{d A_{a}^{\text {DMA }}}{d t}=\left(\sum_{i=1}^{8} Q_{i} \times \frac{C_{i}^{\text {DMA }}}{P_{i}^{\text {DMA }}}-\sum_{i=1}^{8} Q_{i} \times C_{a}^{D M A}\right) \\
& \frac{d A_{\text {Muscle }}^{3+}}{d t}=Q_{\text {Muscle }} \times\left(C_{a}^{3+}-\frac{C_{\text {Muscle }}^{3+}}{P_{\text {Muscle }}^{3+}}\right)+\left(K_{1} \times C_{\text {Muscle }}^{5+}-K_{2} \times C_{\text {Muscle }}^{5+}\right) \times V_{\text {Muscle }} \\
& \frac{d A_{\text {Muscle }}^{5+}}{d t}=Q_{\text {Muscle }} \times\left(C_{a}^{5+}-\frac{C_{\text {Muscle }}^{5+}}{P_{\text {Muscle }}^{5+}}\right)-\left(K_{1} \times C_{\text {Muscle }}^{5+}-K_{2} \times C_{\text {Muscle }}^{3+}\right) \times V_{\text {Muscle }} \\
& \frac{d A_{\text {Muscle }}^{\text {MMA }}}{d t}=Q_{\text {Muscle }} \times\left(C_{a}^{\text {MMA }}-\frac{C_{\text {Muscle }}^{\text {MMA }}}{P_{\text {Muscle }}^{\text {MMA }}}\right) \\
& \frac{d A_{\text {Muscle }}^{\text {DMA }}}{d t}=Q_{\text {Muscle }} \times\left(C_{a}^{D M A}-\frac{C_{\text {Muscle }}^{\text {DMA }}}{P_{\text {Muscle }}^{D M A}}\right)
\end{aligned}
$$

7. Muscle

8. Richly perfused tissues

As(III)

$\frac{d A_{R p t}^{3+}}{d t}=Q_{R p t} \times\left(C_{a}^{3+}-\frac{C_{R p t}^{3+}}{P_{R p t}^{3+}}\right)+\left(K_{1} \times C_{R p t}^{5+}-K_{2} \times C_{R p t}^{3+}\right) \times V_{R p t}$

$\operatorname{As}(\mathrm{V})$

$\frac{d A_{R p t}^{5+}}{d t}=Q_{R p t} \times\left(C_{a}^{5+}-\frac{C_{R p t}^{5+}}{P_{R p t}^{5+}}\right)-\left(K_{1} \times C_{R p t}^{5+}-K_{2} \times C_{R p t}^{3+}\right) \times V_{R p t}$

MMA

$\frac{d A_{R p t}^{M M A}}{d t}=Q_{R p t} \times\left(C_{a}^{M M A}-\frac{C_{R p t}^{M M A}}{P_{R p t}^{M M A}}\right)$

$\frac{d A_{R p t}^{D M A}}{d t}=Q_{R p t} \times\left(C_{a}^{D M A}-\frac{C_{R p t}^{D M A}}{P_{R p t}^{D M A}}\right)$

9. Slowly perfused tissues

As(III)

$\frac{d A_{S p t}^{3+}}{d t}=Q_{S p t} \times\left(C_{a}^{3+}-\frac{C_{S p t}^{3+}}{P_{S p t}^{3+}}\right)+\left(K_{1} \times C_{S p t}^{5+}-K_{2} \times C_{S p t}^{3+}\right) \times V_{S p t}$

$\frac{d A_{S p t}^{5+}}{d t}=Q_{S p t} \times\left(C_{a}^{5+}-\frac{C_{S p t}^{5+}}{P_{S p t}^{5+}}\right)-\left(K_{1} \times C_{S p t}^{5+}-K_{2} \times C_{S p t}^{3+}\right) \times V_{S p t}$

$\operatorname{As}(\mathrm{V})$

$\frac{d A_{S p t}^{M M A}}{d t}=Q_{S p t} \times\left(C_{a}^{M M A}-\frac{C_{S p t}^{M M A}}{P_{S p t}^{M M A}}\right)$

MMA

$\frac{d A_{S p t}^{D M A}}{d t}=Q_{S p t} \times\left(C_{a}^{D M A}-\frac{C_{S p t}^{D M A}}{P_{S p t}^{D M A}}\right)$

DMA

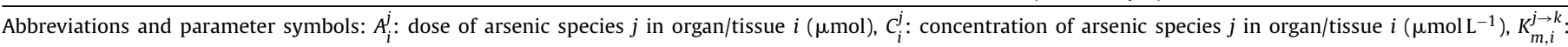

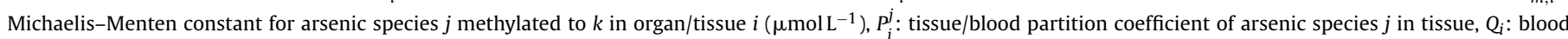

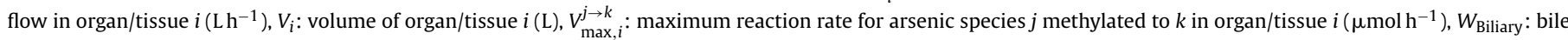

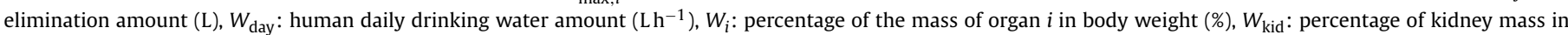
body weight (\%).

\section{References}

[1] C.J. Chen, C.W. Chen, M.M. Wu, T.L. Kuo, Cancer potential in liver, lung, bladder and kidney due to ingested inorganic arsenic in drinking water, Br. J. Cancer 66 (1992) 888-892.

[2] C.J. Chen, Y.M. Hsueh, M.P. Tseng, Y.C. Lin, L.I. Hsu, W.L. Chou, Individual susceptibility to arseniasis, in: Exposure and Health Effect IV, Elsevier Science, Oxford, UK, 2001, pp. 135-143.

[3] C.J. Chen, L.I.Hsu, C.H. Wang, W.L. Shih, Y.H.Hsu, M.P.Tseng, Biomarkers of exposure, effect, and susceptibility of arsenic-induced health hazards in Taiwan, Toxicol. Appl. Pharmacol. 206 (2005) 198-206.

[4] A.H. Smith, P.A. Lopipero, M.N. Bates, C.M. Steinmaus, Arsenic epidemiology and drinking water standards, Science 296 (2002) 2145-2146.

[5] H.Y. Chiou, S.T. Chiou, Y.H. Hsu, Y.L. Chou, C.H. Tseng, M.L. Wei, Incidence of transitional cell carcinoma and arsenic in drinking water: a follow-up study of 8102 residents in an arseniasis-endemic area in northeastern Taiwan, Am. J. Epidemiol. 153 (2001) 411-418.
[6] C.Y. Yang, C.C. Chang, S.S. Tsai, H.Y. Chuang, C.K. Ho, T.N. Wu, Arsenic in drinking water and adverse pregnancy outcome in an arseniasis-endemic area in Northeastern Taiwan, Environ. Res. 91 (2003) 29-34.

[7] J.M. Chiou, S.L. Wang, C.J. Chen, C.R. Deng, W. Lin, T.Y. Tai, Arsenic ingestion and increased microvascular disease risk: observations from the southwestern arseniasis-endemic area in Taiwan, Int. J. Epidemiol. 34 (2005) 936943.

[8] S.H. Lamm, A. Engel, C.A. Penn, R. Chen, M. Feinleib, Arsenic cancer risk confounder in southwest Taiwan data set, Environ. Health Perspect. 114 (2006) 1077-1082.

[9] National Research Council (NRC), Arsenic in Drinking Water, National Academy Press, Washington, DC, 2001.

[10] USEPA, Arsenic in Drinking Water, US Evironmental Protection Agency, Washington DC, 2002

[11] C.A. Loffredo, H.V. Aposhian, M.E. Cebrian, H. Yamauchi, E.K. Silbergeld Variability in human metabolism of arsenic, Environ. Res. 92 (2003) 85-91. 
[12] J. Campain, Metals and inorganic compounds, in: M.B. Reddy, R.S.H. Yang III, H.J. Clewell, M.E. Andersen (Eds.), Physiologically Based Pharmacokinetic Modeling, John Wiley \& Sons, Hoboken, NJ, 2005, pp. 239-270.

[13] D. Yu, A physiologically based pharmacokinetic model of inorganic arsenic Regul. Toxicol. Pharm. 29 (1999) 128-141.

[14] D. Yu, Uncertainties in a pharmacokinetic modeling for inorganic arsenic, J. Environ. Sci. Health A33 (1998) 1369-1390.

[15] D. Yu, A pharmacokinetic modeling of inorganic arsenic: a short-term oral exposure model for humans, Chemosphere 39 (1999) 2737-2747.

[16] S. Mann, P.O. Droz, M. Vahter, A physiologically based pharmacokinetic mode for arsenic exposure. I. Development in hamsters and rabbits, Toxicol. Appl. Pharmacol. 137 (1996) 8-22.

[17] S. Mann, P.O. Droz, M. Vahter, A physiologically based pharmacokinetic model for arsenic exposure. II. Validation and application in humans, Toxicol. Appl. Pharmacol. 140 (1996) 471-486.

[18] E.R. Christensen, N. Nyholm, Ecotoxicological assays with algae-Weibull dose-response curves, Environ. Sci. Technol. 18 (1984) 713-718.

[19] W.F. ten Berge, Kaplan-Meier tumor probability as a starting point for dose-response modeling provides accurate lifetime risk estimates from rodent carcinogenicity studies, Ann. NY Acad. Sci. 895 (1999) 112-124.

[20] R.L. Kodell, J.J. Chen, R.R. Delongchamp, J.F. Young, Hierarchical models for probabilistic dose-response assessment, Regul. Toxicol. Pharm. 45 (2006) 265272.

[21] R.Q. Blackwell, Estimation total arsenic ingested by residents in the endemic blackfoot area, J. Formosan Med. Assoc. 60 (1961) 1143-1144.
[22] P.B. Tchounwou, J.A. Centeno, A.K. Patlolla, Arsenic toxicity, mutagenesis, and carcinogenesis-a health risk assessment and management approach, Mol. Cell. Biochem. 255 (2004) 47-55.

[23] USEPA, Risk-based Concentration Table, January-June, 1996. USEPA Region 3 , Philadelphia, PA, 1996.

[24] K.H. Morales, L. Ryan, T.L. Kuo, M.M. Wu, C.J. Chen, Risk of internal cancers from arsenic in drinking water, Environ. Health. Perspect. 108 (2000) 655-661.

[25] C.L. Chen, L.I. Hsu, H.Y. Chiou, Y.M. Hsueh, S.Y. Chen, M.M. Wu, Ingested arsenic, cigarette smoking, and lung cancer risk: a follow-up study in arseniasisendemic areas in Taiwan, J. Am. Med. Assoc. 292 (2004) 2984-2990.

[26] M.E. Andersen, H.J. Clewell, M.L. Gargas, F.A. Smith, R.H. Reitz, Physiologically based pharmacokinetics and the risk assessment process for methylenechloride, Toxicol. Appl. Pharmacol. 87 (1987) 185-205.

[27] H.J. Clewell, J.M. Gearhart, P.R. Gentry, T.R. Covington, C.B. Van Landingham, A.M. Shipp, Evaluation of the uncertainty in an oral reference dose for methylmercury due to interindividual variability in pharmacokinetics, Risk Anal. 19 (1999) 547-558.

[28] A.M. Hissink, L.W. Wormhoudt, P.J. Sherratt, J.D. Hayes, J.N.M. Commandeur, N.P.E. Vermeulen, P.J. Van Bladeren, A physiologically based pharmacokinetic (PB-PK) model for ethylene dibromide: relevance of extrahepatic metabolism, Food Chem. Toxicol. 38 (2000) 707-716.

[29] D. Yu, J.K. Kim, A physiologically based assessment of human exposure to radon released from groundwater, Chemosphere 54 (2004) 639-645.

[30] Y.C. Huang, Introduction to Anatomy and Physiology, 3rd ed., Hweihua Publishing Company, Taipei, Taiwan, 2000, pp. 589-609, Chap. 14 